\title{
Heats of Formation of Hexacalcium Dialumino Ferrite and Dicalcium Ferrite
}

\author{
E. S. Newman and Roald Hoffman
}

\begin{abstract}
Measurements were made of the heat of solution of $6 \mathrm{CaO} \cdot 2 \mathrm{Al}_{2} \mathrm{O}_{3} \cdot \mathrm{Fe}_{2} \mathrm{O}_{3}$ and $2 \mathrm{CaO} \cdot \mathrm{Fe}_{2} \mathrm{O}_{3}$ in $\mathrm{HCl}, 26.61 \mathrm{H}_{2} \mathrm{O}\left(2.000\right.$ normal at $\left.25^{\circ} \mathrm{C}\right)$. From these data, together with appropriate heat-of-dilution measurements and data taken from the literature, the heats of formation of the two compounds were calculated.
\end{abstract}

\section{Introduction}

The major part of the iron in portland cement clinker is found in combination with lime and alumina in the form of solid solutions between the compounds $6 \mathrm{CaO} \cdot 2 \mathrm{Al}_{2} \mathrm{O}_{3} \cdot \mathrm{Fe}_{2} \mathrm{O}_{3}$ and $2 \mathrm{CaO} \cdot \mathrm{Fe}_{2} \mathrm{O}_{3}[1] .{ }^{1}$ One such solution, brownmillerite, had been recognized earlier as an important constituent of portland cement [2]. Thorvaldsen, Edwards, and Bailey [3] determined the heat of formation of this material, and Lerch and Bogue [4] measured its heat of hydration. A general investigation of the thermochemistry of the compounds occurring in hydraulic cements is being conducted at the National Bureau of Standards. The heats of solution of solid solutions of $6 \mathrm{CaO} \cdot 2 \mathrm{Al}_{2} \mathrm{O}_{3} \cdot \mathrm{Fe}_{2} \mathrm{O}_{3}$ and $2 \mathrm{CaO} \cdot \mathrm{Fe}_{2} \mathrm{O}_{3}$, measured in a mixture of nitric and hydrofluoric acids, were given in a previous paper [5]. The present paper gives the heats of solution of these two compounds in hydrochloric acid and the heats of formation calculated therefrom.

\section{Experimental Procedure and Results}

\subsection{Thermochemical Equations}

Heats of formation are usually obtained by the addition of a considerable number of thermochemical equations. The equations must be written with the proper coefficients to agree with the stoichiometry of the reactions they describe and to fit the experimental conditions chosen. After a few experimental conditions have been arbitrarily selected, others in subsequent experiments will be fixed by the relationships among the equations. To find these conditions, the entire series of thermochemical equations must be written in detail. For this reason, the thermochemical equations for the determination of the heats of formation of $6 \mathrm{CaO} \cdot 2 \mathrm{Al}_{2} \mathrm{O}_{3} \cdot \mathrm{Fe}_{2} \mathrm{O}_{3}$ and $2 \mathrm{CaO} \cdot \mathrm{Fe}_{2} \mathrm{O}_{3}$ are given here. For completeness, the heats of reaction are also given, although some of the values were obtained as the experimental results of the work described hereafter. The arbitrarily selected experimental conditions were based on the volume of the heat-ofsolution calorimeter and the solubilities of the substances involved. The conditions chosen were such that a sample weight of $1 \mathrm{~g}$ of powdered sample would be dissolved in $600.0 \mathrm{~g}$ of $2.000 \mathrm{~N} \mathrm{HCl}\left(\mathrm{HCl}, 26 \cdot 61_{4} \mathrm{H}_{2} \mathrm{O}\right.$ at $\left.25^{\circ} \mathrm{C}\right)$. Upon this basis the following thermochemical equations were written. The reasons for their use will be apparent or will be discussed later. Unless otherwise noted, the equations are written for isothermal reactions at $25^{\circ} \mathrm{C}$.

$$
\text { a. Heat of Formation of } 6 \mathrm{CaO} \cdot 2 \mathrm{Al}_{2} \mathrm{O}_{3} \cdot \mathrm{Fe}_{2} \mathrm{O}_{3}
$$

The heat of formation of $6 \mathrm{CaO} \cdot 2 \mathrm{Al}_{2} \mathrm{O}_{3} \cdot \mathrm{Fe}_{2} \mathrm{O}_{3}$ from the oxides may be obtained by summing the equations

$\left(784.1 \mathrm{HCl}, \quad 6 \mathrm{CaCl}_{2}, \quad 4 \mathrm{AlCl}_{3}, \quad 2 \mathrm{FeCl}_{3}, \quad 21680 \mathrm{H}_{2} \mathrm{O}\right)($ soln $) \rightarrow 6 \mathrm{CaO} \cdot 2 \mathrm{Al}_{2} \mathrm{O}_{3} \cdot \mathrm{Fe}_{2} \mathrm{O}_{3}(\mathrm{c})+814.1(\mathrm{HCl}$, $\left.26.61 \mathrm{H}_{2} \mathrm{O}\right)$ (soln), $\Delta H_{1}=402.41 \mathrm{kcal}$.

$6 \mathrm{CaO}(\mathrm{c})+12\left(\mathrm{HCl}, 26.61 \mathrm{H}_{2} \mathrm{O}\right)(\mathrm{soln}) \rightarrow 6\left(\mathrm{CaCl}_{2}, 53.23 \mathrm{H}_{2} \mathrm{O}\right)($ soln $)+6 \mathrm{H}_{2} \mathrm{O}(\mathrm{l}), \quad \Delta H_{2}=-280.58$ keal.

\footnotetext{
${ }_{1}$ Figures in brackets indicate the literature references at the end of this paper.
} 
$6 \mathrm{H}_{2} \mathrm{O}(\mathrm{l})+6\left(\mathrm{CaCl}_{2}, 53.23 \mathrm{H}_{2} \mathrm{O}\right)($ soln $) \rightarrow 6\left(\mathrm{CaCl}_{2} \cdot 54.23 \mathrm{H}_{2} \mathrm{O}\right)($ soln $), \quad \Delta H_{3}=-0.06 \quad \mathrm{kcal}$.

$\mathrm{Fe}_{2} \mathrm{O}_{3}\left(\mathrm{c}, 20^{\circ} \mathrm{C}\right)+6\left(\mathrm{HCl}, 200 \mathrm{H}_{2} \mathrm{O}\right)\left(\operatorname{soln}, 20^{\circ} \mathrm{C}\right) \rightarrow 2\left(\mathrm{FeCl}_{3}, 601.5 \mathrm{H}_{2} \mathrm{O}\right)\left(\mathrm{soln}, 20^{\circ} \mathrm{C}\right), \quad \Delta H_{4}=$ -24.74 kcal.

$\mathrm{Fe}_{2} \mathrm{O}_{3}\left(\mathrm{c}, 25^{\circ} \mathrm{C}\right) \rightarrow \mathrm{Fe}_{2} \mathrm{O}_{3}\left(\mathrm{c}, 20^{\circ} \mathrm{C}\right), \quad \Delta H_{5}=-0.124 \quad \mathrm{kcal}$.

$6\left(\mathrm{HCl}, 200 \mathrm{H}_{2} \mathrm{O}\right)\left(\operatorname{soln}, 25^{\circ} \mathrm{C}\right) \rightarrow 6\left(\mathrm{HCl}, 200 \mathrm{H}_{2} \mathrm{O}\right)\left(\operatorname{soln}, 20^{\circ} \mathrm{C}\right), \quad \Delta H_{6}=-107.13 \mathrm{kcal}$.

$2\left(\mathrm{FeCl}_{3}, 601.5 \mathrm{H}_{2} \mathrm{O}\right)\left(\operatorname{soln}, 20^{\circ} \mathrm{C}\right) \rightarrow 2\left(\mathrm{FeCl}_{3}, 601.5 \mathrm{H}_{2} \mathrm{O}\right)\left(\right.$ soln, $\left.25^{\circ} \mathrm{C}\right) \quad \Delta H_{7}=107.79 \mathrm{kcal}$.

$2\left(\mathrm{FeCl}_{3}, 601.5 \mathrm{H}_{2} \mathrm{O}\right)($ soln $) \rightarrow 2\left(\mathrm{FeCl}_{3}, 81.34 \mathrm{H}_{2} \mathrm{O}\right)($ soln $)+1040 \mathrm{H}_{2} \mathrm{O}, \quad \Delta H_{3}=4.028$ kcal.

$6\left(\mathrm{HCl}, 26.61 \mathrm{H}_{2} \mathrm{O}\right)(\mathrm{soln})+1040 \mathrm{H}_{2} \mathrm{O} \rightarrow 6\left(\mathrm{HCl}, 200 \mathrm{H}_{2} \mathrm{O}\right)(\mathrm{soln}), \quad \Delta H_{9}=-2.568 \mathrm{kcal}$.

$2 \mathrm{Al}_{2} \mathrm{O}_{3}(\mathrm{c}, \alpha)+12\left(\mathrm{HCl}, 26.61 \mathrm{H}_{2} \mathrm{O}\right)(\mathrm{soln}) \rightarrow 4\left(\mathrm{AlCl}_{3}, 81.34 \mathrm{H}_{2} \mathrm{O}\right)($ soln $), \quad \Delta H_{10}=-119.44 \mathrm{kcal}$.

$6\left(\mathrm{CaCl}_{2}, 54.23 \mathrm{H}_{2} \mathrm{O}\right)($ soln $)+784.1\left(\mathrm{HCl}, 26.61 \mathrm{H}_{2} \mathrm{O}\right)(\mathrm{soln}) \rightarrow\left(784.1 \mathrm{HCl}, 6 \mathrm{CaCl}_{2}, 21190 \mathrm{H}_{2} \mathrm{O}\right)(\mathrm{soln})$, $\Delta H_{11}=0.29 \mathrm{kcal}$.

$4\left(\mathrm{AlCl}_{3}, 81.34 \mathrm{H}_{2} \mathrm{O}\right)(\mathrm{soln})+\left(784.1 \mathrm{HCl}, 6 \mathrm{CaCl}_{2}, 21190 \mathrm{H}_{2} \mathrm{O}\right)(\mathrm{soln}) \rightarrow\left(784.1 \mathrm{HCl}, 6 \mathrm{CaCl}_{2}, 4 \mathrm{AlCl}_{3}\right.$, $\left.21520 \mathrm{H}_{2} \mathrm{O}\right)(\mathrm{soln}), \quad \Delta H_{12}=0.48 \mathrm{kcal}$.

$2\left(\mathrm{FeCl}_{3}, 81.34 \mathrm{H}_{2} \mathrm{O}\right)+\left(784.1 \mathrm{HCl}, 6 \mathrm{CaCl}_{2}, 4 \mathrm{AlCl} 21520 \mathrm{H}_{2} \mathrm{O}\right)($ soln $) \rightarrow\left(784.1 \mathrm{HCl}, 6 \mathrm{CaCl}_{2}, 4 \mathrm{AlCl}_{3}\right.$, $\left.2 \mathrm{FeCl}_{3}, 21680 \mathrm{H}_{2} \mathrm{O}\right)(\operatorname{soln}), \quad \Delta H_{13}=1.35 \mathrm{kcal}$.

The sum of eq (2) and (3) is

$6 \mathrm{CaO}(\mathrm{c})+12\left(\mathrm{HCl}, 26.61 \mathrm{H}_{2} \mathrm{O}\right)(\mathrm{soln}) \rightarrow 6\left(\mathrm{CaCl}_{2}, 54.23 \mathrm{H}_{2} \mathrm{O}\right)($ soln $), \quad \Delta H_{14}=-280.64 \mathrm{kcal}$.

The sum of eq (4) to (9), inclusive, is

$\mathrm{Fe}_{2} \mathrm{O}_{3}(\mathrm{c})+6\left(\mathrm{HCl}, 26.61 \mathrm{H}_{2} \mathrm{O}\right)(\mathrm{soln}) \rightarrow 2\left(\mathrm{FeCl}_{3}, 81.34 \mathrm{H}_{2} \mathrm{O}\right)($ soln $), \Delta H_{15}=-22.74 \mathrm{kcal}$.

These two equations (14 and 15) represent the solution of two of the oxide constituents of $6 \mathrm{CaO} \cdot 2 \mathrm{Al}_{2} \mathrm{O}_{3} \cdot \mathrm{Fe}_{2} \mathrm{O}_{3}$ in $\mathrm{HCl}, 26.61 \mathrm{H}_{2} \mathrm{O}$.

The sum of eq (1) to (13), inclusive, represents the formation of $6 \mathrm{CaO} \cdot 2 \mathrm{Al}_{2} \mathrm{O}_{3} \cdot \mathrm{Fe}_{2} \mathrm{O}_{3}$ from the oxides,

$$
\begin{gathered}
6 \mathrm{CaO}(\mathrm{c})+2 \mathrm{Al}_{2} \mathrm{O}_{3}(\mathrm{c}, \alpha)+\mathrm{Fe}_{2} \mathrm{O}_{3}(\mathrm{c}) \rightarrow 6 \mathrm{CaO} \cdot 2 \mathrm{Al}_{2} \mathrm{O}_{3} \cdot \mathrm{Fe}_{2} \mathrm{O}_{3}(\mathrm{c}), \quad \Delta H_{16}=-18.29 \mathrm{kcal} . \\
\text { b. Heat of Formation of } 2 \mathrm{CaO} \cdot \mathrm{Fe}_{2} \mathrm{O}_{3}
\end{gathered}
$$

In a similar manner, the heat of formation of $2 \mathrm{CaO} \cdot \mathrm{Fe}_{2} \mathrm{O}_{3}$ from the oxides was obtained from the equations

$\left(306.2 \mathrm{HCl}, \quad 2 \mathrm{CaCl}_{2}, \quad 2 \mathrm{FeCl}_{3}, \quad 8419 \mathrm{H}_{2} \mathrm{O}\right)(\mathrm{soln}) \rightarrow 2 \mathrm{CaO} \cdot \mathrm{Fe}_{2} \mathrm{O}_{3}(\mathrm{c})+316.2\left(\mathrm{HCl}, \quad 26.61 \mathrm{H}_{2} \mathrm{O}\right)(\operatorname{soln})$, $\Delta H_{17}=107.40 \mathrm{kcal}$.

$2 \mathrm{CaO}(\mathrm{c})+4\left(\mathrm{HCl}, 26.61 \mathrm{H}_{2} \mathrm{O}\right)(\mathrm{soln}) \rightarrow 2\left(\mathrm{CaCl}_{2}, 54.23 \mathrm{H}_{2} \mathrm{O}\right)($ soln $), \Delta H_{18}=-93.55 \mathrm{kcal}$.

$\mathrm{Fe}_{2} \mathrm{O}_{3}(\mathrm{c})+6\left(\mathrm{HCl}, 26.61 \mathrm{H}_{2} \mathrm{O}\right)(\mathrm{soln}) \rightarrow 2\left(\mathrm{FeCl}_{3}, 81.34 \mathrm{H}_{2} \mathrm{O}\right)($ soln $), \quad \Delta H_{15}=-22.74 \mathrm{kcal}$. $2\left(\mathrm{CaCl}_{2}, 54.23 \mathrm{H}_{2} \mathrm{O}\right)(\mathrm{soln})+306.2\left(\mathrm{HCl}, 26.61 \mathrm{H}_{2} \mathrm{O}\right)(\mathrm{soln}) \rightarrow\left(306.2 \mathrm{HCl}, 2 \mathrm{CaCl}_{2}, 8256 \mathrm{H}_{2} \mathrm{O}\right)(\operatorname{soln})$,

$$
\Delta H_{19}=0.11 \mathrm{kcal} \text {. }
$$

$2\left(\mathrm{FeCl}_{3}, 81.34 \mathrm{H}_{2} \mathrm{O}\right)(\mathrm{soln})+\left(306.2 \mathrm{HCl}, 2 \mathrm{CaCl}_{2}, 8256 \mathrm{H}_{2} \mathrm{O}\right)($ soln $) \rightarrow\left(306.2 \mathrm{HCl}, 2 \mathrm{CaCl}_{2}, 2 \mathrm{FeCl}_{3}\right.$, $\left.8419 \mathrm{H}_{2} \mathrm{O}\right)(\mathrm{soln}), \quad \Delta H_{20}=1.34 \mathrm{kcal}$.

The sum of the above five equations represents the formation of $2 \mathrm{CaO} \cdot \mathrm{Fe}_{2} \mathrm{O}_{3}$ from the oxides,

$$
2 \mathrm{CaO}(\mathrm{c})+\mathrm{Fe}_{2} \mathrm{O}_{3}(\mathrm{c}) \rightarrow 2 \mathrm{CaO} \cdot \mathrm{Fe}_{2} \mathrm{O}_{3}(\mathrm{c}), \quad \Delta H_{21}=-7.44 \mathrm{kcal} .
$$




\subsection{Preparation of the Samples}

The samples of dicalcium ferrite and hexacalcium dialumino ferrite used in this investigation were the same ones used in the previous work [5], and their preparation has been described. Because in 8 years of storage the ignition losses had become about 0.2 percent, the samples were sintered overnight at $1,200^{\circ} \mathrm{C}$ and reground for $2 \mathrm{hr}$ in a power-driven mortar just before the beginning of the present heat-of-solution measurements. The heat-of-dilution experiments were performed with solutions of calcium chloride, aluminum chloride, and ferric chloride prepared from analytical reagents. The manufacturers' lot analyses were assumed correct, because the heat effects to be measured were small and minor errors in the concentrations of the solutions would have a negligible effect on the measured values.

\subsection{Apparatus and Procedure}

\section{a. Heats of Solution}

All experiments were performed in an air-conditioned room controlled at $25 \pm 0.8^{\circ} \mathrm{C}$ and a maximum relative humidity of 50 percent. The heats of solution were determined using 1 -g samples in an isothermal-jacket calorimeter [6] containing $600.0 \mathrm{~g}$ of $\mathrm{HCl}, 26.61_{4} \mathrm{H}_{2} \mathrm{O}$. The temperature changes were measured with a 25.5 -ohm platinum resistance thermometer, Mueller bridge, and a galvanometer with an 8-m optical lever. The sensitivity of the measuring system was such that a scale deflection of $1 \mathrm{~mm}$ corresponded to a temperature change of about $0.000073 \mathrm{deg} \mathrm{C}$. The corrected temperature rises were calculated according to the method described by White [7, p. 42]. Time-temperature data were taken with the aid of a chronograph during the rapid-rise portion of the experimental period, and the area under the time-temperature curve was obtained by using the trapezoidal rule. The $1-\mathrm{g}$ samples dissolved in 30 to $40 \mathrm{~min}$. The powdered samples were kept in the balance case, the temperature of which was recorded, and appropriate corrections were made for the sensible heat introduced into the calorimeter with the samples, using $0.2 \mathrm{cal} / \mathrm{g}$ for their specific heat. The final calorimeter temperature was always within a few hundredths of a degree of $25.00^{\circ} \mathrm{C}$, and no further corrections were made to bring the measured isothermal heats of solution to that reference temperature. The thermochemical calorie of 4.1840 absolute joules was used. The calorimeter containing the solvent acid was calibrated electrically [14, p. 217] over approximately the temperature range covered by the heat-of-solution measurements. The standard cell and standard resistors used in measuring the electric energy were calibrated by the Electricity and Electronics Division of the Bureau, and the input was timed using a chronograph and the standard seconds signals originating in the Mechanics Division. The resistance thermometer was used in the customary manner without converting resistance changes to degrees Celsius. Hence the energy equivalent was obtained in calories per ohm, and is approximately equal to calories per $9.901 \mathrm{deg}$ C.

\section{b. Heats of Dilution}

The heats of dilution were determined in a calorimeter consisting of a 1-pt wide-mouthed vacuum flask partially submerged in a constant-temperature water bath. The cork and upper end of the flask were protected from room-temperature variations by a double-walled copper cap dipping into the water, as suggested by White [7, p. 152]. The liquid sample was held in a thin-walled glass bulb with a long stem. The bulb was placed beneath the surface of the calorimeter acid with the stem held in a clamp above the copper cap. A thin glass rod was placed so as to rest in the bulb with the upper end protruding slightly above the stem, and a $40-\mathrm{cm}$ glass tube of larger diameter was attached to the stem with a short piece of rubber tubing. An 8-g weight was held at the top of the tube, to which was connected a $100-\mathrm{ml}$ reservoir containing air at a gage pressure of about $0.3 \mathrm{lb} / \mathrm{in}^{2}$. To introduce the sample, the weight was allowed to fall, and the impact drove the lower end of the rod through the bulb. A small quantity of air passed through the tube until the pressure in the reservoir fell to about $0.1 \mathrm{lb} / \mathrm{in}^{2}$. The pressure was then released to allow the stem of the bulb to fill to 
the liquid level in the calorimeter. This somewhat elaborate system was used to insure complete and prompt introduction of the sample. The arrangement of the calorimeter required that the bulb be placed off center, and the stem frequently broke if the bulb was simply pushed against the hemispherical bottom of the vacuum flask. On the other hand, the rod frequently punched only a small hole through the bottom of the bulb, and the air pressure was necessary to make certain that the sample passed into the calorimeter acid.

Three-hundred-seventy-gram quantities of $\mathrm{HCl}, 26.61_{4} \mathrm{H}_{2} \mathrm{O}$ or of distilled water were used in the calorimeter. The heat-of-dilution experiments were performed by using proportions of acid or of water to solution such that the final concentrations should be identical with those in the heat-of-solution determinations. The concentrations and quantities to be used in each experiment were calculated from the appropriate thermochemical equation listed in section 2.1. The calorimeter was calibrated electrically, using the same procedure and equipment described in the preceding section. The heat capacities of the solutions contained in the sample bulbs were estimated from the apparent molal heat capacities of the solutes, and the energy equivalent of the vacuum flask calorimeter and its contents was increased correspondingly. Here again the heat effects to be measured were small, and small errors in the heat capacity did not affect the final results significantly. The final temperature of the calorim . eter was always close to $25.00^{\circ} \mathrm{C}$, and, as in the heat-of-solution measurements, no further corrections were made to obtain the heats of dilution at the reference temperature. Using the platinum resistance thermometer described in section 2.3.a, the bridge current was reversed each time the calorimeter temperature was recorded. This reversal, by doubling the observed deflection, doubled the sensitivity of the measurements. The very small corrected temperature changes during the experimental period were calculated by graphical or analytical extrapolation of the time-temperature data observed during the initial and final rating periods [14, p. 232].

The heat effect of breaking the sample bulbs was determined by performing heat-of-dilution experiments in which the solution in the bulb was the same as that in the calorimeter. Under these conditions, no dilution effects would occur. The average value of this blank determination was subtracted from each heat-of-dilution measurement.

\subsection{Experimental Results}

In table 1 are given the results of the calibration experiments for the heat-of-solution calorimeter, and of the heat-of-solution and heat-of-dilution measurements. The measured heat effects of breaking a number of sample bulbs such as were used in the heat-of-dilution

TABLE 1. Calorimetric results

\begin{tabular}{|c|c|c|c|c|c|c|c|c|}
\hline \multirow{3}{*}{$\begin{array}{l}\text { Energy equiv- } \\
\text { alent of heat- } \\
\text { of-solution } \\
\text { calorimeter }\end{array}$} & \multicolumn{4}{|c|}{$6 \mathrm{CaO} \cdot 2 \mathrm{Al}_{2} \mathrm{O}_{3} \cdot \mathrm{Fe}_{2} \mathrm{O}_{3}$} & \multicolumn{3}{|c|}{$2 \mathrm{CaO} \cdot \mathrm{Fe}_{2} \mathrm{O}_{3}$} & \multirow{3}{*}{ Blank } \\
\hline & \multirow{2}{*}{$\begin{array}{l}\text { Heat of } \\
\text { solution }\end{array}$} & \multicolumn{3}{|c|}{ Heat of mixing of solutions } & \multirow{2}{*}{$\begin{array}{l}\text { Heat of } \\
\text { solution }\end{array}$} & \multicolumn{2}{|c|}{$\begin{array}{l}\text { Heat of mixing of } \\
\text { solutions }\end{array}$} & \\
\hline & & $\begin{array}{c}\mathrm{CaCl}_{2}, \\
54.23 \mathrm{H}_{2} \mathrm{O} \\
(\mathrm{eq} \mathrm{11})\end{array}$ & $\begin{array}{c}\mathrm{AlCl}_{3}, \\
81.34 \mathrm{H}_{2} \mathrm{O} \\
(\text { eq } 12)\end{array}$ & $\begin{array}{c}\mathrm{FeCl}_{3}, \\
81.34 \mathrm{H}_{2} \mathrm{O} \\
(\text { eq } 13)\end{array}$ & & $\begin{array}{c}\mathrm{CaCl}_{2}, \\
54.34 \mathrm{H}_{2} \mathrm{O} \\
(\text { eq 19) }\end{array}$ & $\begin{array}{c}\mathrm{FeCl}_{3}, \\
81.34 \mathrm{H}_{2} \mathrm{O} \\
(\text { eq } 20)\end{array}$ & \\
\hline $\begin{array}{r}\mathrm{cal} / \mathrm{ohmb} \\
5813.25 \\
5815.06 \\
5813.57 \\
5821.04 \\
5820.62 \\
\end{array}$ & $\begin{array}{l}\text { cal } / g \\
575.77 \\
570.13 \\
578.48 \\
573.80 \\
575.88 \\
575.17 \\
574.25 \\
575.08\end{array}$ & $\begin{array}{r}c a l / g c \\
-0.38 \\
-.43 \\
-.42 \\
-.44 \\
-.38 \\
-\end{array}$ & $\begin{array}{r}c a l / g c \\
-0.75 \\
-.65 \\
-.70 \\
-.64 \\
-\end{array}$ & $\begin{array}{l}\text { cal/gc } \\
-1.96 \\
-1.94 \\
-1.83 \\
-1.97 \\
-1.94 \\
-\end{array}$ & $\begin{array}{c}\text { cal/g } \\
394.91 \\
395.88 \\
394.55 \\
394.32 \\
394.32 \\
395.02 \\
396.43 \\
\end{array}$ & $\begin{array}{c}c a l / g c \\
-0.48 \\
-.39 \\
-.44 \\
-.34 \\
-\end{array}$ & $\begin{array}{l}c a l / g c \\
-4.98 \\
-4.82 \\
-5.00 \\
-4.90 \\
- \\
-\end{array}$ & $\begin{array}{c}c a l \\
0.04 \\
.02 \\
.02 \\
.06 \\
.05 \\
.0-\end{array}$ \\
\hline Avg 5816. 70 & 574.82 & -0.410 & -0.685 & -1.928 & 395.06 & -0.412 & -4.925 & .048 \\
\hline S. D.d 1.71 & 0.83 & .015 & .025 & 0.025 & 0.25 & .030 & 0.041 & .012 \\
\hline
\end{tabular}

a Heat effect of breaking the bulb containing the solution.

${ }^{b} \triangle \mathrm{R} / \triangle \mathrm{T}$ is approximately $0.1010 \mathrm{ohm} / \mathrm{deg}$ at $25^{\circ} \mathrm{C}$. Therefore, $5816.70 \mathrm{cal} / \mathrm{ohm}$ is approximately $587.5 \mathrm{cal} /{ }^{\circ} \mathrm{C}$.

- Calories per gram of ferrite comound. These quantities have been corrected for the average energy of breaking the bulbs.

d Standard deviation of the average, $\sqrt{\left[\Sigma x^{2}-(\Sigma x)^{2} / n\right] / n(n-1)}$. 
experiments are also given. The observed heats of dilution were corrected for the average observed energy of breaking the sample bulb before being calculated to the basis of $1 \mathrm{~g}$ of powdered sample as given in table 1.

\subsection{Heats of Formation}

The procedure for calculating the heats of formation of the two ferrites from the oxides has been outlined by the equations in section 2.1. The experiments and calculations represented by the equations will now be discussed.

\section{a. Heat of Formation of $6 \mathrm{CaO} \cdot 2 \mathrm{Al}_{2} \mathrm{O}_{3} \cdot \mathrm{Fe}_{2} \mathrm{O}_{3}$}

Equation (1) represents the experimental determination of the heat of solution of $6 \mathrm{CaO} \cdot 2 \mathrm{Al}_{2} \mathrm{O}_{3} \cdot \mathrm{Fe}_{2} \mathrm{O}_{3}$, converted to a molar basis. The equation is written in reverse for addition, the sign of the heat effect being changed. The experimental results in table 1 give the value $402.41 \pm 0.58 \mathrm{kcal} /$ mole for the heat of solution. (The standard deviation of the average is given here and elsewhere in this paper.)

Equations (2) and (3) together represent the measurement of the heat of solution of 6 moles of calcium oxide in an equivalent amount of hydrochloric acid. The heat of reaction $\Delta \mathrm{H}_{2}$ was calculated from heat-of-formation data taken from Circular 500 of the National Bureau of Standards [13]. Revised values [11] were used for the heat of formation of HCl, aq. The data for $\mathrm{CaCl}_{2}$ solutions [13] were plotted and $\Delta \mathrm{H}_{3}$ was calculated as the slope of the curve of the heat of formation versus $n$, at $n=54$ moles of water per mole of $\mathrm{CaCl}_{2}$.

The heat of solution of $\mathrm{Fe}_{2} \mathrm{O}_{3}$ in $\mathrm{HCl}, 26.61 \mathrm{H}_{2} \mathrm{O}$ cannot be determined directly, because $\mathrm{Fe}_{2} \mathrm{O}_{3}$ will not dissolve. Thorvaldsen, Edwards, and Bailey [3] determined the heat of solution in $\mathrm{HCl}, 200$ at $20^{\circ} \mathrm{C}$ by an indirect method. Equations (5) to (9) represent the recalculation of their result, given as eq (4), to the appropriate conditions for the present investigation, i. e., the heat of solution at $25^{\circ} \mathrm{C}$ in $\mathrm{HCl}, 26.61 \mathrm{H}_{2} \mathrm{O}$. Equations (5), (6), and (7) represent the heat effect of changing the temperature of the reaction to $25^{\circ} \mathrm{C}$. The heat capacity value of $24.7 \mathrm{cal} / \mathrm{deg}-\mathrm{mole}$ used in calculating $\Delta H_{5}$ was taken from Kelley's compilation of low-temperature heat capacities [9]. Revised values [11] for the apparent heat capacity of $\mathrm{HCl}$, aq. were used in estimating the value $-29.3 \mathrm{cal} / \mathrm{deg}$-mole for the apparent heat capacity of $\mathrm{HCl}$, $200 \mathrm{H}_{2} \mathrm{O}$ over the range $20^{\circ}$ to $25^{\circ} \mathrm{C}$. This value was used in calculating $\Delta H_{6}$. The apparent heat capacity of $\mathrm{FeCl}_{3}, 601.5 \mathrm{H}_{2} \mathrm{O}$, used in calculating $\Delta H_{7}$, was determined by a plot of heat capacity versus the square root of the molality, calculated from the data of Kangro and Flugge [10]. The value $-51.4 \mathrm{cal} / \mathrm{deg}-$ mole at $20^{\circ} \mathrm{C}$ was obtained. It was estimated [11] that the apparent heat capacity would become about $1 \mathrm{cal} / \mathrm{deg}$-mole more positive for each degree rise in temperature, and the average value $-48.9 \mathrm{cal} / \mathrm{deg}$-mole was used for the change from $20^{\circ}$ to $25^{\circ} \mathrm{C}$ represented by eq $(7)$.

To obtain the value of $\Delta H_{8}$, the dilution experiment represented by eq (8) (written in reverse) was performed. Ferric chloride solutions are subject to hydrolysis and the formation of complexes, and relatively few heat-of-dilution data are available [10]. A few drops of $\mathrm{HCl}$ were added to the ferric chloride solution to stabilize it. The heat effect possibly caused by the presence of this small amount of acid was ignored, as Thorvaldsen and his coworkers [3] found that the heat of mixing of $\left(\mathrm{FeCl}_{3}, 600 \mathrm{H}_{2} \mathrm{O}+\mathrm{HCl}, 200 \mathrm{H}_{2} \mathrm{O}\right)$ with $\mathrm{HCl}, 200 \mathrm{H}_{2} \mathrm{O}$ was negligible. The heat-of-dilution value $-2.014 \pm 0.014 \mathrm{kcal} / \mathrm{mole}$ was found as the average of five determinations. Equation (9) represents the dilution of $\mathrm{HCl}, 26.61 \mathrm{H}_{2} \mathrm{O}$ to $\mathrm{HCl}, 200 \mathrm{H}_{2} \mathrm{O}$. The heat effect of this reaction was calculated from the revised values of the heat of formation of $\mathrm{HCl}$, aq. The sum of eq (4) to (9) gives

$$
\mathrm{Fe}_{2} \mathrm{O}_{3}(\mathrm{c})+6\left(\mathrm{HCl}, 26.61 \mathrm{H}_{2} \mathrm{O}\right)(\text { soln }) \rightarrow 2\left(\mathrm{FeCl}_{3}, 81.34 \mathrm{H}_{2} \mathrm{O}\right) \quad(\text { soln }), \quad \Delta H_{15}-22 \cdot 74 \mathrm{kcal} .
$$

Aluminum oxide, like ferric oxide, cannot be dissolved in $\mathrm{HCl}, 26.61 \mathrm{H}_{2} \mathrm{O}$. Its heat of solution was calculated in an earlier paper [12]. The calculation was repeated by using the revised heats of formation of hydrochloric acid solutions, and $\Delta H_{10}$ was obtained. 
Equations (11), (12), and (13) represent a dilution experiment in which solutions of $\mathrm{CaCl}_{2}$. $\mathrm{AlCl}_{3}$, and $\mathrm{FeCl}_{3}$ were added in succession to a single calorimeter charge of $\mathrm{HCl}, 26.61 \mathrm{H}_{2} \mathrm{O}$, The proportions and concentrations to be used were calculated from the equations, and the experiment was performed a number of times. The detailed results are given in table 1 . The average values obtained were calculated to the basis of 1 mole of $6 \mathrm{CaO} \cdot 2 \cdot \mathrm{Al}_{2} \mathrm{O}_{3} \cdot \mathrm{Fe}_{2} \mathrm{O}_{3}$, and are given as $0.29,0.48$, and $1.35 \mathrm{kcal}$ for $\Delta H_{11}, \Delta H_{12}$, and $\Delta H_{13}$ respectively. The corresponding standard deviations are $\pm 0.010, \pm 0.017$, and \pm 0.017 keal, respectively.

The summation of eq (1) to (13), inclusive, gives eq (16), representing the formation of $6 \mathrm{CaO} \cdot 2 \mathrm{Al}_{2} \mathrm{O}_{3} \cdot \mathrm{Fe}_{2} \mathrm{O}_{3}$ from the oxides,

$$
6 \mathrm{CaO}(\mathrm{c})+2 \mathrm{Al}_{2} \mathrm{O}_{3}(\mathrm{c}, \alpha)+\mathrm{Fe}_{2} \mathrm{O}_{3}(\mathrm{c}) \rightarrow 6 \mathrm{CaO} \cdot 2 \mathrm{Al}_{2} \mathrm{O}_{3} \cdot \mathrm{Fe}_{2} \mathrm{O}_{3}(\mathrm{c}), \Delta \mathrm{H}-18.29 \mathrm{kcal} .
$$

The standard deviation of the heat of formation, estimated from the sum of the variances of the heats of reaction entering into its calculation, is about $\pm 0.6 \mathrm{kcal} / \mathrm{mole}$.

\section{b. Heat of Formation of $2 \mathrm{CaO} \cdot \mathrm{Fe}_{2} \mathrm{O}_{3}$}

The heat of formation of dicalcium ferrite was calculated in a manner analogous to that of $6 \mathrm{CaO} \cdot 2 \mathrm{Al}_{2} \mathrm{O}_{3} \cdot \mathrm{Fe}_{2} \mathrm{O}_{3}$. Equation (14) represents the heat of solution of $2 \mathrm{CaO} \cdot \mathrm{Fe}_{2} \mathrm{O}_{3}$ written in reverse. The heat of solution, calculated from the data in table 1 , was $107.40 \pm 0.068 \mathrm{kcal} / \mathrm{mole}$. Equation (18), which is one-third of eq (14), represents the heat of solution of 2 moles of $\mathrm{CaO}$ in $\mathrm{HCl}, 26.61 \mathrm{H}_{2} \mathrm{O}$, with a heat effect of $-93.55 \mathrm{kcal}$. Equation (15) has been discussed. The last two equations, (19) and (20), represent the appropriate heat-of-dilution measurements in which first $\mathrm{CaCl}_{2}$ and then $\mathrm{FeCl}_{3}$ solution was added to a single calorimeter acid charge. The experiment was performed, in proportions of solution to acid calculated from the equations, and the values 0.11 and $1.34 \mathrm{kcal}$ per mole of $2 \mathrm{CaO} \cdot \mathrm{Fe}_{2} \mathrm{O}_{3}$ obtained for $\Delta H_{19}$ and $\Delta H_{20}$, respectively. The corresponding standard deviations are \pm 0.008 and $\pm 0.011 \mathrm{kcal}$, respectively. The summation of the equations indicated in section 2.1.b gives eq (21;, representing the formation of $2 \mathrm{CaO} \cdot \mathrm{Fe}_{2} \mathrm{O}_{3}$ from the oxides.

$$
2 \mathrm{CaO}(\mathrm{c})+\mathrm{Fe}_{2} \mathrm{O}_{3}(\mathrm{c}) \rightarrow 2 \mathrm{CaO} \cdot \mathrm{Fe}_{2} \mathrm{O}_{3}(\mathrm{c}), \quad \Delta H_{21}=-7.44 \mathrm{kcal} .
$$

The standard deviation of the heat of formation, estimated in a similar manner to that of $6 \mathrm{CaO} \cdot 2 \mathrm{Al}_{2} \mathrm{O}_{3} \cdot \mathrm{Fe}_{2} \mathrm{O}_{3}$, is about $0.1 \mathrm{kcal} / \mathrm{mole}$.

\section{Summary}

Measurements were made of the heat of solution of $6 \mathrm{CaO} \cdot 2 \mathrm{Al}_{2} \mathrm{O}_{3} \cdot \mathrm{Fe}_{2} \mathrm{O}_{3}$ and $2 \mathrm{CaO} \cdot \mathrm{Fe}_{2} \mathrm{O}_{3}$ in $\mathrm{HCl}, 26.61 \mathrm{H}_{2} \mathrm{O}\left(2.00 \mathrm{~N}\right.$ at $\left.25^{\circ} \mathrm{C}\right)$. Heats of dilution of aqueous $\mathrm{CaCl}_{2}, \mathrm{AlCl}_{3}$, and $\mathrm{FeCl}_{3}$ in the same acid were also determined. From these measurements and from data in the literature, the heats of formation of the two compounds from the oxides were calculated to be -18.3 and $-7.4 \mathrm{kcal} / \mathrm{mole}$, respectively.

\section{References}

[1] M. A. Swayze, Am. J. Science $\mathbf{2 4 4}, 1-30$ (1946).

[2] R. H. Bogue, ind. Eng. Chem. Anal. Ed. 1, 192 (1929).

[3] T. Thorvaldsen, R. R. Edwards, and E. C. Bailey, Z. anorg. u. allgem. Chem. 236, 310 (1938).

[4] W. Lerch and R. H. Bogue, BS J, Research 12, 645 (1934) RP 684.

[5] E. S. Newman, J. Research NBS 38, 661 (1947) RP 1805.

[6] E. S. Newman, J. Research NBS 54, 347 (1955) RP 2597.

[7] W. P. White, The modern calorimeter (The Chemical Catalog Co., New York, N. Y., 1928).

[8] E. S. Newman and L. S. Wells, J. Research NBS 20, 825 (1938) RP 1107.

[9] K. K. Kelley, U. S. Bureau of Mines Bulletin 477 (1950).

[10] W. Kangro and R. Flugge, Z. phys. Chem. 175, 187 (1935).

[11] W. H. Evans (private communication).

[12] R. B. Peppler and E. S. Newman, J. Research NBS 4\%, 439 (1951) RP2269.

[13] F. D. Rossini, D. D. Wagman, W. H. Evans, S. Levine, and I. Jaffe, NBS Circ. 500 (1952).

[14] H. C. Dickenson, Bul. BS 11, 189 (1915) S230.

WAshington, January 4, 1956. 